(1)

\title{
Mechanisms for PACAP-induced prolactin gene expression in grass carp pituitary cells
}

\author{
Chengyuan Lin1,2,3, Xue Jiang', Mulan He', Ling Zhao², Tao Huang², Zhaoxiang Bian²,3 \\ and Anderson O L Wong'
}

1School of Biological Sciences, University of Hong Kong, Hong Kong

${ }^{2}$ Clinical Division, School of Chinese Medicine, Hong Kong Baptist University, Hong Kong

${ }_{3}$ YMU-HKBU Joint Laboratory of Traditional Natural Medicine, Yunnan Minzu University,

Kunming, China

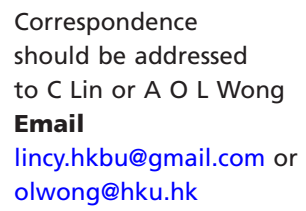

\begin{abstract}
In mammals, pituitary adenylate cyclase-activating polypeptide (PACAP) is a pleiotropic hormone with diverse functions but its role in prolactin (PRL) regulation is highly controversial. To shed light on Prl regulation by PACAP in fish model, grass carp pituitary cells was used as a model to examine the receptor specificity and signal transduction for PACAP modulation of prl gene expression in the carp pituitary. Using RT-PCR, PACAP-selective PAC1 receptor was detected in carp lactotrophs. In carp pituitary cells, nanomolar doses of PACAP, but not VIP, could elevate Prl secretion and protein production with concurrent rise in prl mRNA and these stimulatory effects were blocked by PACAP antagonist but not VIP antagonist. PACAP-induced prl mRNA expression could be mimicked by activating adenylate cyclase (AC), increasing CAMP level by CAMP analog, or increasing intracellular $\mathrm{Ca}^{2+}\left(\left[\mathrm{Ca}^{2+}\right] \mathrm{i}\right)$ by $\mathrm{Ca}^{2+}$ ionophore/voltage-sensitive $\mathrm{Ca}^{2+}$ channel (VSCC) activator. PACAP-induced prl gene expression, however, was attenuated/ abolished by suppressing CAMP production, inhibiting PKA activity, blocking [Ca2+] i mobilization and VSCC activation, calmodulin (CaM) antagonism, and inactivation of JNK and CaM Kinase II (CaMK-II). Similar sensitivity to CaM, JNK, and CaMK-II blockade was also noted by substituting CAMP analog for PACAP as the stimulant for prl mRNA expression. These results, as a whole, provide evidence for the first time that (i) PACAP activation of PAC1 receptor expressed in carp lactotrophs could induce Prl synthesis and secretion, and (ii) Prl production induced by PACAP was mediated by upregulation of prl gene expression, presumably via functional coupling of CAMP/PKA-, Ca2+/CaM-, and MAPK-dependent cascades.
\end{abstract}

\author{
Key Words \\ - prolactin \\ - PACAP \\ - PAC-I receptor \\ - signal transduction \\ - pituitary \\ - grass carp
}

\section{Introduction}

Pituitary adenylate cyclase-activating polypeptide (PACAP), a member of the secretin/glucagon family, is a 38-amino acid (a.a.) peptide isolated from ovine hypothalamus with stimulatory activity on cAMP production in rat pituitary cells (Miyata et al. 1989). In mammals, two forms of PACAP have been reported, namely PACAP $_{38}$ and PACAP 27 (Miyata et al. 1989, 1990). The a.a. sequence of PACAP is highly conserved from fish

Published by Bioscientifica Ltd. 
to mammals, especially in the N-terminal 27-a.a. region (Xu et al. 2012), and with high levels of structural homology to the related peptide vasoactive intestinal peptide (VIP) (Moody et al. 2011). The biological functions of PACAP are mediated by three subtypes of PACAP receptors, including PAC1, VPAC1 and VPAC2 receptors, functionally coupled to cAMP/PKA-, PLC/PKC-, and $\mathrm{Ca}^{2+-d e p e n d e n t ~ c a s c a d e s ~}$ (Harmar et al. 2012). In mammals, the PAC1 receptor is specific for PACAP and with high affinity for PACAP but not VIP, whereas the VPAC receptors can bind PACAP and VIP with similar affinity (Vaudry et al. 2009).

In mammals, VIP is well-documented as a stimulator for prolactin (PRL) release (Christian et al. 2007) but the functional role of PACAP in PRL regulation is controversial and the data published are highly variable and contradictory to one another. For examples, the central effect via ICV injection of PACAP, which is inhibitory to PRL release in vivo (Tohei et al. 2009), is different from the results of systemic administration (e.g., IV infusion) with either no effect (Sawangjaroen \& Curlewis 1994) or stimulation on plasma PRL level (Jarry et al. 1992). At pituitary level (e.g., in rat pituitary cells), the direct effect of PACAP on PRL regulation is also not consistent, as stimulatory (Benter et al. 1995), inhibitory (Jarry et al. 1992), and no effect has been reported (Hart et al. 1992). Although PAC1 and VPAC receptors can be detected at the pituitary level (Vertongen et al. 1996), no consensus has been reached regarding the receptor specificity for PRL regulation by PACAP. For the signal transduction of PACAP, the previous studies on PRL regulation were largely based on pituitary cell lines/tumor cells with little information for primary cell culture. Besides, the results obtained are fragmentary and with inconsistency among different reports. For example, PACAP was shown to upregulate PRL promoter activity via cAMP and MEK/ERK pathways in GH3 cells (Mijiddorj et al. 2011). In another study with the same cell model, cAMP was found to be not involved in PACAP-induced $p r l$ gene transcription (Coleman \& Bancroft 1993). Recently, inhibition of prl promoter activity in GH3 cells by prolonged treatment with PACAP, probably via cAMP- and MAPK-dependent mechanisms, has also been reported (Mijiddorj et al. 2013). To date, a comprehensive model for the post-receptor signaling of PRL regulation by PACAP is still lacking and a systematic study on signal transduction based on primary culture of pituitary cells/purified lactotrophs is clearly warranted.

In fish models, Prl is a pleiotropic hormone from the pituitary with diverse functions, especially for osmoregulation and ion transport in freshwater adaptation (Shu et al. 2016, Watanabe et al. 2016). Except for a single report on goldfish with Prl release induced by PACAP but with no effect on prl mRNA expression (Matsuda et al. 2008), no information is available regarding the receptor specificity or signal transduction for PRL regulation by PACAP in lower vertebrates, including fish species. In our recent studies, grass carp prl has been cloned and its expression in the pars distalis of the carp pituitary has been confirmed (Lin et al. 2015). Besides, nerve fibers with PACAP immunoreactivity could be located in the pars distalis of carp pituitary overlapping with the distribution of somatotrophs and lactotrophs (Wong et al. 2005), and in parallel study with carp pituitary cells, PACAP was shown to induce growth hormone $(\mathrm{GH})$ secretion and gene expression via cAMP/ PKA- and $\mathrm{Ca}^{2+} / \mathrm{CaM}$-dependent mechanisms (Sze et al. 2007). Given that PACAP nerve fibers were located in the vicinity of carp lactotrophs, this anatomical finding has prompted us to speculate that PACAP may play a role in Prl regulation in carp pituitary. To test the hypothesis, static incubation of grass carp pituitary cells was conducted to examine the effects of PACAP treatment on Prl secretion, prl production, and prl transcript expression via direct actions acting at the pituitary level. Receptor specificity for the pituitary actions of PACAP was investigated using a pharmacological approach with antagonists for PAC1 and VPAC receptors. The signal transduction involved in PACAP regulation of prl gene expression were also elucidated using specific blockers for cAMP/PKA, $\mathrm{Ca}^{2+} / \mathrm{CaM}, \mathrm{PLC} / \mathrm{PKC}$, and MAPK cascades. The results obtained were further confirmed by direct measurement of second messengers produced during the process of PACAP induction. Our findings for the first time provide evidence that (i) PACAP activation of PAC1 receptor in carp lactotrophs could induce PRL synthesis and secretion and (ii) the stimulatory effect of PACAP on Prl production was mediated by upregulation of prl gene expression, presumably via functional coupling of cAMP/ PKA-, $\mathrm{Ca}^{2+} / \mathrm{CaM}-$, and MAPK-dependent cascades.

\section{Materials and methods}

\section{Animals}

One-year-old Chinese grass carp (Ctenopharyngodon idellus) with body weights ranging from 1.5 to $2.0 \mathrm{~kg}$ were purchased from local markets and kept in a wellaerated 200-L aquaria under a 12-h L:12-h D photoperiod at $18 \pm 2^{\circ} \mathrm{C}$. The fish were sacrificed under anesthesia with $0.05 \%$ tricaine methanesulfonate (Sigma) followed by spinosectomy according to protocol approved by the

Published by Bioscientifica Ltd. 
Committee for Animal Use in Research and Teaching at University of Hong Kong (Hong Kong).

\section{Reagents and test substances}

Minimum essential medium (MEM), $\mathrm{Ca}^{2+}$-free MEM, TRIzol reagent, fetal bovine serum (FBS), type II trypsin, DNase I/II, and antibiotic-antimycotic stock solution were purchased from Invitrogen. Ovine PACAP $_{38}$, human VIP, cod VIP, ovine PACAP ${ }_{6-38}$, and (4-Cl-D-Phe6, Leu17)VIP were purchased from Phoenix Pharmaceuticals (Belmont, CA, USA), whereas grass carp PACAP $_{38}$ (purity: 93\%) was synthesized by HSC Biotechnology Services Center (University of Toronto, Canada). Forskolin, H89, MDL12330A, 3-isobutyl-1methylxanthine (IBMX), 8-(4-chloro phenylthio)-cAMP (cpt-cAMP), A23187, Bay K8644, nifedipine, verapamil, 2-aminoethoxydiphenyl borate (2-APB), xestospongin C (XeC), U73122, KN62/93, calmidazolium, TPA, GF109203, U0126, PD169316, Ly294002, (L)-JNKI 1 , and SP600125 were obtained from Calbiochem. Peptide hormones were dissolved in double-distilled deionized water and frozen stored as $0.1 \mathrm{mM}$ stocks in small aliquots at $-80^{\circ} \mathrm{C}$. The pharmacological agents were prepared in similar manner except that the stock solutions were dissolved in dimethyl sulfoxide (DMSO). On the day of the experiment, stock solutions of test substances were diluted with pre-warmed $\left(28^{\circ} \mathrm{C}\right)$ culture medium to appropriate concentrations $15 \mathrm{~min}$ prior to drug treatment. The final dilutions of DMSO were always less than $0.1 \%$ and had no effects on Prl release and $p r l$ mRNA expression in grass carp pituitary cells.

\section{Grass carp pituitary cell culture}

Primary culture of grass carp pituitary cells were prepared by trypsin/DNase II digestion method as described previously (Wong et al. 1998), cultured in poly-D-lysine precoated 24 -well cluster plate at a density of $2.5 \times 10^{6}$ cells/well, and incubated overnight $(\sim 15 \mathrm{~h})$ in plating medium (MEM with $26 \mathrm{mM} \mathrm{NaHCO}_{3}$, $25 \mathrm{mM}$ HEPES, and $1 \%$ antibiotic-antimycotic; $\mathrm{pH}$ 7.7) with $5 \% \mathrm{FBS}$ at $28^{\circ} \mathrm{C}$ under $5 \% \mathrm{CO}_{2}$ and saturated humidity. On the following day, the culture medium was replaced with serum-free testing medium (MEM with $26 \mathrm{mM} \mathrm{NaHCO}, 25 \mathrm{mM}$ HEPES, and $1 \%$ antibiotic-antimycotic; pH 7.7) with $1 \%$ BSA and drug treatment was initiated for the duration as indicated in individual experiments.

\section{Immunostaining and LCM capture of grass carp lactotrophs}

Immunostaining was performed in Cytospin preparation of grass carp pituitary cells seeded at a density of $\sim 5 \times 10^{4}$ cells/slide using a Vectastain ABC Kit (Vector Lab, Burlingame, CA, USA) with the antiserum for carp PRL $(1: 10,000)$ and GH $(1: 50,000)$, respectively (Lin et al. 2015). After signal development, immunoidentified lactotrophs and somatotrophs were isolated from mixed populations of pituitary cells by laser-capture microdissection (LCM) using a PixCell-II Cell Isolation Workstation (Arcturus, Mountain View, CA, USA). During cell capturing, the infrared laser was set at $65 \mathrm{~mW}$ with pulse duration at $0.8-1.2 \mathrm{~ms}$ and beam diameter at $7.5 \mu \mathrm{m}$. A total of 50 cells were captured for individual cell types and dissolved in TRIzol for RNA isolation. After DNase I digestion and reverse transcription with SuperScript III (Invitrogen), the RT samples were subjected to PCR with primers for grass carp PAC1R (Accession No: EU305549, F2: 5'-CGTGTTTGAACTTGGTCTTGG-3'; R1: 5'-GAGCTGCTCTTGCTGAGGAT-3'). PCR was conducted for 40 cycles with denaturation at $94^{\circ} \mathrm{C}$ for $30 \mathrm{~s}$, annealing at $50^{\circ} \mathrm{C}$ for $30 \mathrm{~s}$, and extension at $72^{\circ} \mathrm{C}$ for $30 \mathrm{~s}$. PCR products obtained were size-fractionated in a $1 \%$ agarose gel and visualized by ethidium bromide staining. In this study, RT-PCR of GAPDH was used as the internal control.

\section{Western blot for PRL expression in carp pituitary cells}

Carp pituitary cells were seeded in poly-D-lysine coated 24 -well culture plates at a density of $2.5 \times 10^{6} \mathrm{cells} / \mathrm{mL} /$ well and incubated with test substances for $48 \mathrm{~h}$ at $28^{\circ} \mathrm{C}$ under $5 \% \mathrm{CO}_{2}$ and saturated humidity. After drug treatment, the culture medium was collected and centrifuged at $1500 \mathrm{~g}$. The supernatant obtained was used as the samples for PRL release. The cells remaining in individual wells were lysed for $30 \mathrm{~min}$ on ice with frequent agitations in $100 \mu \mathrm{L} /$ well RIPA medium (50 mM Tris-HCl, 1\% Nonidet-P40, $0.25 \%$ sodium deoxycholate, $1 \mathrm{mM}$ EDTA, and $150 \mathrm{mM}$ $\mathrm{NaCl}$ ) supplemented with protease and phosphatase inhibitor cocktail (Roche). The lysate was harvested and cell debris was removed by centrifugation at $10,000 \boldsymbol{g}$ at $4^{\circ} \mathrm{C}$ for $10 \mathrm{~min}$. The supernatant was collected and used as samples for PRL cell content. Samples for total Prl production were reconstituted for individual wells by pro rata pooling of the protein samples for Prl release and cell content. Prior to Western blot, the protein content of the cell lysate and/or culture medium was determined using a BCA protein assay kit (Thermo Fisher). After that, protein

Published by Bioscientifica Ltd 
samples ( $20 \mu \mathrm{g} / \mathrm{lane})$ was resolved in $10 \%$ gel by SDS-PAGE and transblotted onto PVDF membranes by low-current electrotransfer at $50 \mathrm{~mA}$ for $1 \mathrm{~h}$ at RT using a Hoefer TE70 Semi-Dry Transfer Unit (Pharmacia). Prl signals were detected with the antiserum for carp Prl $(1: 20,000)$ according to the standard procedures for Western blot (Lin et al. 2015). A similar approach was also used to probe CaM expression using the antibody for human CaM (1:1000; Upstate). In these studies, Western blot for $\beta$-actin was used as internal control with the antibody for mouse $\beta$-actin (1:15,000; Oncogen, Cambridge, MA, USA).

\section{Real-time PCR for PRL mRNA measurement}

Pituitary cells were seeded in 24-well plates at a density of $2.5 \times 10^{6} \mathrm{cells} / \mathrm{mL} /$ well. After drug treatment, culture medium was aspirated and pituitary cells were dissolved in TRIzol reagent. Total RNA was extracted, digested with DNase I, and reversely transcribed with SuperScript III according to standard protocols. RT samples obtained were then subjected to real-time PCR for $\mathrm{prl}$ mRNA measurement with primers for carp prl (PRL-1: 5'-CTCAGCACCTCTCTCACCAATGACC-3' and PRL2: 5'-GCGGAAGCAGGACAACAGAAAATG-3') using a LightCycler SYBR Green Master kit (Roche) as described previously (Lin et al. 2015). PCR was initiated by a denaturing step at $94^{\circ} \mathrm{C}$ for $3 \mathrm{~min}$, followed by 35 cycles of denaturation at $94^{\circ} \mathrm{C}$ for $30 \mathrm{~s}$, annealing at $55^{\circ} \mathrm{C}$ for $30 \mathrm{~s}$, and extension at $72^{\circ} \mathrm{C}$ for $30 \mathrm{~s}$. Melting curve analysis was performed to verify the PCR product for prl mRNA (with $T_{\mathrm{m}}$ of $93.6^{\circ} \mathrm{C}$ ). In these experiments, serial dilutions of plasmid DNA carrying the coding sequence of carp prl were used as the standards. Parallel real-time PCR for $18 \mathrm{~S}$ RNA was also performed to serve as the internal control.

\section{Measurement of cAMP production}

The rostral pars distalis (RPD) of carp pituitaries were manually dissected under a stereomicroscope and pituitary cells (referred to as 'RPD cells') were prepared as previously described (Zhou et al. 2004). The RPD cells were then seeded at a density of $\sim 2 \times 10^{6}$ cells $/ 2 \mathrm{~mL} /$ dish in polyD-lysine precoated $35-\mathrm{mm}$ dishes and cultured overnight at $28^{\circ} \mathrm{C}$ in carp MEM with 5\% FBS. On the following day, carp MEM was replaced with $0.9 \mathrm{~mL}$ of HEPES-buffered Hanks balanced salt solution (Wang et al. 2007) with $0.1 \%$ BSA and 0.1 mM IBMX. IBMX, a phosphodiesterase inhibitor, was included to prevent cAMP degradation in the cell culture. Drug treatment was initiated by adding
$0.1 \mathrm{~mL}$ of the $10 \times$ stocks of PACAP prepared at appropriate concentrations. The cells were then incubated at $28^{\circ} \mathrm{C}$ for $15 \mathrm{~min}$. After that, culture medium was harvested and used for measurement of cAMP secretion, whereas cellular cAMP content was extracted from RPD cells using $1 \mathrm{~mL}$ ice-cold absolute ethanol. The samples collected were freeze-dried and stored at $-20^{\circ} \mathrm{C}$ until their cAMP contents quantified by a BioTrak [125I]cAMP RIA Kit (Amersham). In these studies, total cAMP production was defined as the sum of cellular cAMP content and the amount of cAMP released into the culture medium in individual culture dishes.

\section{Measurement of intracellular $\mathrm{Ca}^{2+}$ levels}

Carp pituitary cells were seeded at a density of $1 \times 10^{4}$ cells/ coverslip on poly-D-lysine precoated Cell-locate Cover Glass (Thermo Fisher Scientific) and cultured in plating medium with $10 \%$ FBS. After overnight incubation, the culture medium was replaced with Krebs-Ringer (K-R) Buffer $\left(120 \mathrm{mM} \mathrm{NaCl}, 4.7 \mathrm{mM} \mathrm{KCl}, 0.7 \mathrm{mM} \mathrm{MgSO}_{4}\right.$, $1.2 \mathrm{mM} \mathrm{CaCl}_{2}, 10 \mathrm{mM}$ glucose, and $15 \mathrm{mM}$ HEPES; $\mathrm{pH}$ 7.4). For single-cell $\mathrm{Ca}^{2+}$ imaging, the cells were preloaded for $45 \mathrm{~min}$ at room temperature with the $\mathrm{Ca}^{2+}$-sensitive dye Fura-2/AM $(5 \mu \mathrm{M}$, Molecular Probes). After that, the cells were rinsed with K-R buffer and incubated for 10-15 min to allow for cytoplasmic de-esterification of the Fura-2/AM dye. Detection of intracellular $\mathrm{Ca}^{2+}\left(\left[\mathrm{Ca}^{2+}\right] \mathrm{i}\right)$ signals was conducted at room temperature $\left(\sim 22^{\circ} \mathrm{C}\right)$ using a epifluorescence microscopy with a PTI DeltaScan System (Photon Technology, West Sussex, UK). Emission signals were monitored at $510 \mathrm{~nm}$ with excitation wavelength alternating between 340 and $380 \mathrm{~nm}$ at 1-s interval. Test substances were introduced gently into the imaging chamber with the cells attached to Cell-locate coverslip by hand pipetting. For the studies under $\mathrm{Ca}^{2+}$ free condition, old medium was replaced with K-R buffer prepared without $\mathrm{CaCl}_{2}$ and supplemented with $1 \mathrm{mM}$ EGTA. After $\mathrm{Ca}^{2+}$ imaging, lactotrophs were identified by immunohistochemical staining using the antiserum for Prl as described in the preceding section.

\section{Data transformation and statistical analysis}

'Steady-state' prl mRNA was quantified by real-time PCR using standard curve calibration as described previously (Lin et al. 2015). Since no significant changes were noted for 18S RNA in our studies, the raw data for prl mRNA (in fmol/tube) were simply transformed as a percentage 
of the mean value in the control group (as ' $\% \mathrm{Ctrl}^{\prime}$ ). For Western blot, the protein levels were quantified in terms of 'arbitrary density unit' after densitometric scanning using ImageJ (https://imagej.nih.gov/ij/) and transformed as a percentage of the control group (\% Ctrl) without drug treatment in a similar way. For cAMP experiments, cAMP levels were measured in terms of 'picomole cAMP/ well' for cAMP release and cellular cAMP content, respectively. These data were then used to calculate total cAMP production for individual wells and normalized as a function of cell number (expressed as 'picomole cAMP produced $/ 1 \times 10^{6}$ cells'). For $\left[\mathrm{Ca}^{2+}\right] \mathrm{i}$ measurements, calibration of $\mathrm{Ca}^{2+}$ concentration was not performed mainly due to variations in dye loading between individual experiments. In our study, the ratio of Fura-2 emission signals detected under excitation wavelength at $340 \mathrm{~nm}$ and $380 \mathrm{~nm}$ was used as index for [Ca $\left.{ }^{2+}\right] \mathrm{i}$ levels (expressed as 'F340/F380 Ratio'). The data presented (as mean \pm S.E.M.) were analyzed by Student's $t$-test or ANOVA followed by Fisher's least significance difference test. Differences were considered significant at $P<0.05$.

\section{Results}

\section{Effects of PACAP on PRL secretion and production}

To study the functional role of PACAP in regulating Prl synthesis and secretion at the pituitary level, static incubation was conducted in primary culture of grass carp pituitary cells with PACAP and VIP of mammalian and fish origin for $48 \mathrm{~h}$. As shown in Fig. 1A and B, increasing levels of ovine and grass carp PACAP (0.1-1000nM) could stimulate Prl release and Prl production in a dosedependent manner without notable effects on Prl cell content. The minimal effective concentration for PACAP stimulation was within the $1-10 \mathrm{nM}$ dose range while the maximal Prl responses were noted in the $10-100 \mathrm{nM}$ dose range. In parallel experiments, increasing concentrations of human and cod VIP $(0.1-100 \mathrm{nM})$ were not effective in altering basal levels of PRL release, PRL cell content, and total Prl production (Fig. 1C and D). Nevertheless, a rise in Prl secretion was detected with VIP treatment at $1000 \mathrm{nM}$ dose but with no significant changes in Prl cell content and total production. To test if the effect of PACAP on Prl production was caused by stimulation of prl gene expression, pituitary cells were treated with increasing doses of PACAP (0.1-1000 nM) and total RNA harvested was used for prl mRNA measurement (Fig. 2A and B). In this case, grass carp and ovine PACAP were both effective in triggering a dose-dependent increase in prl mRNA expression at the pituitary level. The minimal effective dose for PACAP induction was $1 \mathrm{nM}$ with maximal response observed at $10 \mathrm{nM}$ level. In parallel studies with human and cod VIP, despite the trend of a gradual rise in basal levels, no significant increase in prl gene expression was observed in carp pituitary cells with VIP treatment within the doses of 0.1-100 nM (Fig. 2A and B).

Given that the differential effects of PACAP and VIP on Prl production and gene expression were in agreement with the pharmacological profile of PAC1 but not VPAC receptors, the possible involvement of PAC1 receptor in prl regulation by PACAP was also examined. As a first
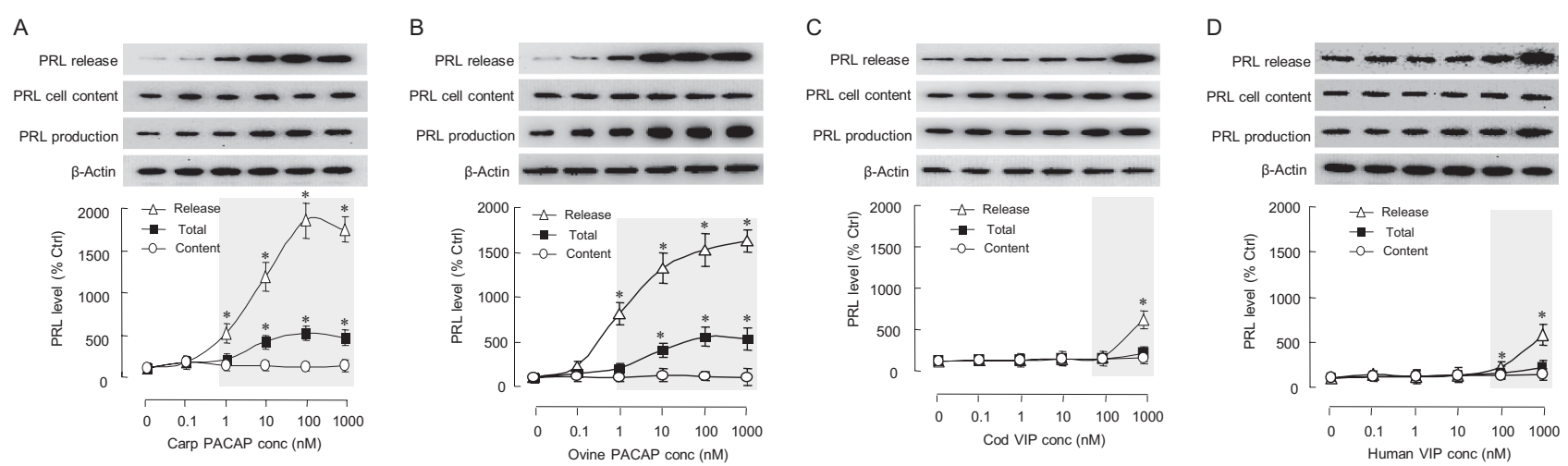

\section{Figure 1}

Effects of PACAP and VIP on Prl secretion, Prl cell content, and total Prl production in grass carp pituitary cells. Pituitary cells were treated with grass carp PACAP 38 (A), ovine PACAP 38 (B), cod VIP (C), or human VIP (D) for $48 \mathrm{~h}$. After drug treatment, culture medium was collected to monitor Prl release and cell lysates were prepared for detection of Prl cell content. Samples from the same well for Prl release and Prl cell content were pooled pro rata to reconstitute the protein sample for total Prl production. In these studies, parallel probing of $\beta$-actin expression was used as internal control. Data presented are expressed as mean \pm S.E.M. $(N=4)$ and are pooled results of four separate experiments. The asterisk $(*)$ represents a significant difference compared to the respective control (Student's $t$-test, $P<0.05$ ).

http://joe.endocrinology-journals.org DOI: $10.1530 / \mathrm{JOE}-16-0433$
() 2017 Society for Endocrinology Printed in Great Britain
Published by Bioscientifica Ltd 
A

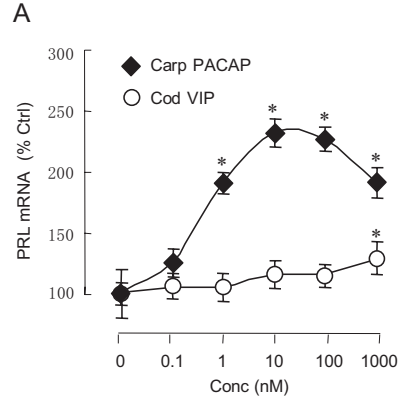

B

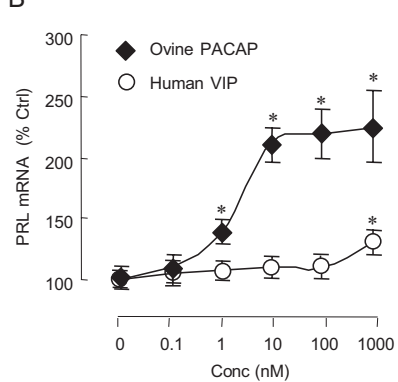

D

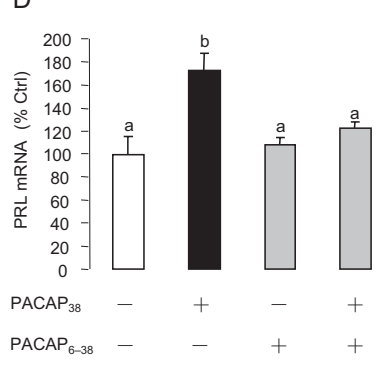

E $_{250}$

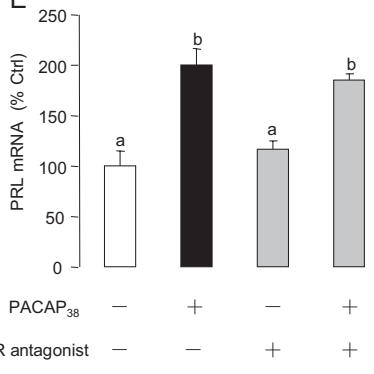

C
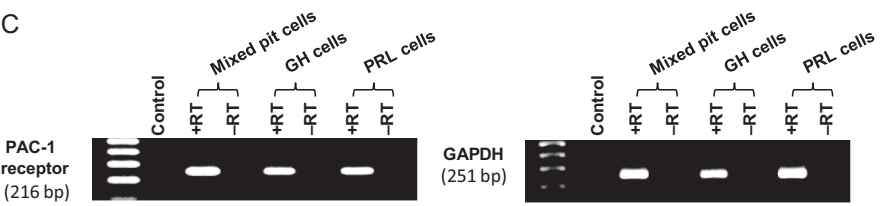

Figure 2

Receptor specificity of PACAP-induced prl mRNA expression in grass carp pituitary cells. Differential effects of PACAP and VIP on prl mRNA expression. Pituitary cells were treated for $48 \mathrm{~h}$ with increasing doses of (A) grass carp PACAP or cod VIP and (B) ovine PACAP 38 or human VIP. Involvement of PAC-I receptor in PACAP induction of prl gene expression at pituitary level. (C) Detection of PAC-I receptor expression in grass carp lactotrophs. Lactotrophs identified by Prl immunostaining ('Prl cells') were isolated from mixed populations of carp pituitary cells by laser capture microdissection and subjected to RT-PCR using primers for carp PAC-I receptor. Parallel capture of immuno-identified somatotrophs ('Gh cells') was used as a positive control. RT-PCR in RNA samples with/without reverse transcription $( \pm R T)$ was conducted to check for genomic DNA contamination while parallel RT-PCR for gapdh mRNA was used as the internal control. Effects of PACAP and VIP antagonists on PACAP-induced prl mRNA expression. In these experiments, pituitary cells were challenged with ovine PACAP $_{38}(10 \mathrm{nM}, 48 \mathrm{~h})$ in the presence or absence of (D) the PACAP antagonist PACAP ${ }_{6-38}(100 \mathrm{nM})$ or (E) VIP antagonist (4-Cl-DPhe6, Leu17)VIP ('VIP-R antagonist', $100 \mathrm{nM}$ ). After drug treatment, total RNA was isolated and subjected to real-time PCR for prl mRNA measurement. Except for the gel pictures for RT-PCR, data presented are expressed as mean \pm s.E.M. $(N=4)$ and are pooled results of four separate experiments. For dose-response studies with PACAP/VIP treatment, the asterisk (*) represents a significant difference compared to the respective control (Student's $t$-test, $P<0.05$ ). For the corresponding studies with PACAP/VIP antagonist, different letters denote a significant difference at $P<0.05$ (ANOVA followed by Fisher's LSD test).

step, RT-PCR for PAC1 receptor was performed in LCMcaptured immuno-identified grass carp lactotrophs. Similar to the results with mixed populations of pituitary cells and immuno-identified somatotrophs (as positive control of the experiment), the 216-bp PCR product for PAC1 receptor was consistently detected in grass carp lactotrophs (Fig. 2C). To further confirm the involvement of PAC1 receptor in PACAP-induced prl gene expression, carp pituitary cells were treated with ovine PACAP $_{38}$ $(10 \mathrm{nM})$ with/without simultaneous treatment with the PACAP antagonist PACAP ${ }_{6-38}(100 \mathrm{nM}$, Fig. 2D) or VIP antagonist (4-Cl-D-Phe ${ }^{6}, \mathrm{Leu}^{17}$ )VIP (100 nM, Fig. 2E). In this case, PACAP-induced prl transcript expression were blocked by the co-treatment with the PACAP antagonist PACAP $_{6-38}$, but not the VIP antagonist (4-Cl-D-Phe6, $\mathrm{Leu}^{17}$ VIP.

\section{Involvement of CAMP/PKA pathway in PACAP-induced PRL gene expression}

To evaluate the possible involvement of cAMP-dependent mechanisms in PACAP induction of prl gene expression in the carp pituitary, the effects of PACAP on cAMP synthesis were tested in grass carp RPD cells. RPD cells were used as lactotrophs which are known to be concentrated in the RPD region of the carp pituitary (Wong et al. 1998). In this experiment, cAMP release, cAMP cell content, and total cAMP production were upregulated in a dose-dependent manner with increasing levels of ovine PACAP $_{38}(0.1-$ $1000 \mathrm{nM})$ (Fig. 3A). In parallel studies, the membranepermeable cAMP analog cpt-cAMP (10-1000 $\mu \mathrm{M}$, Fig. 3B) and AC activator forskolin (100-1000 nM, Fig. 3C) were found to mimic the stimulatory effect of PACAP on prl mRNA expression in carp pituitary cells. In contrast, PACAP (10 nM)-induced prl mRNA expression was totally abolished by co-treatment with the AC inhibitor MDL12330A $(20 \mu \mathrm{M})$ or PKA inhibitor H89 $(20 \mu \mathrm{M})$ (Fig. 3D). Treatment with the two inhibitors alone also suppressed basal expression of $\mathrm{prl}$ mRNA in carp pituitary cells.

\section{Involvement of $\mathrm{Ca}^{2+} / \mathrm{CaM}$-dependent pathways in PACAP-induced PRL gene expression}

In carp pituitary cells, PACAP can induce Gh secretion and gene expression via activation of the http://joe.endocrinology-journals.org DOI: $10.1530 / J O E-16-0433$
○ 2017 Society for Endocrinology Printed in Great Britain 
A
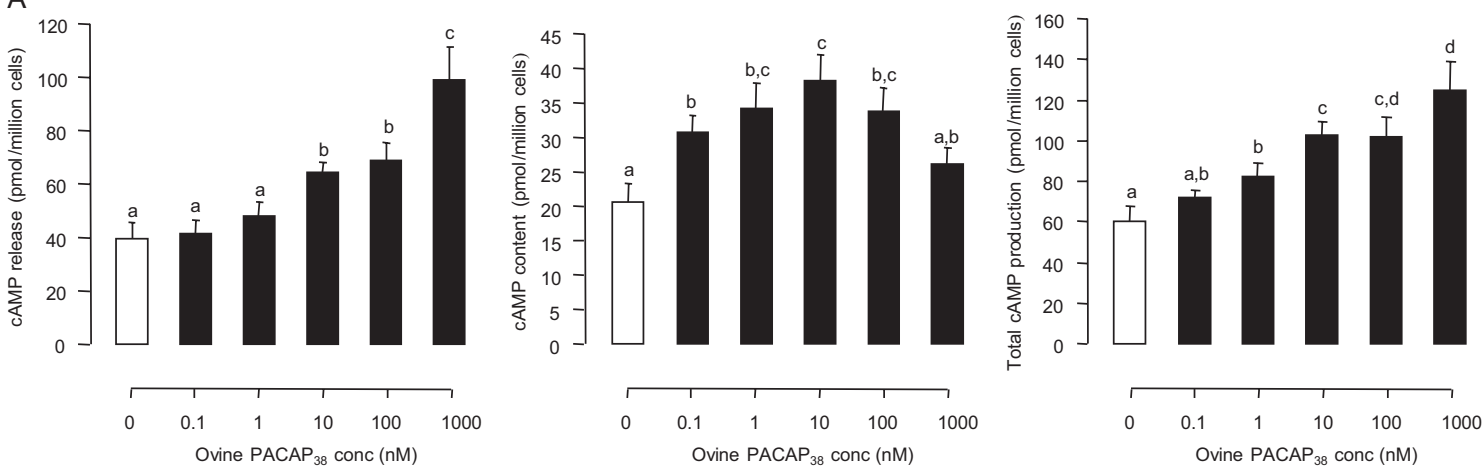

B

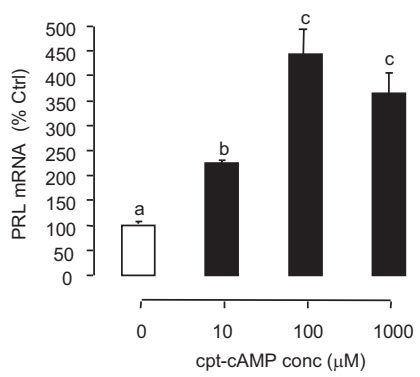

C

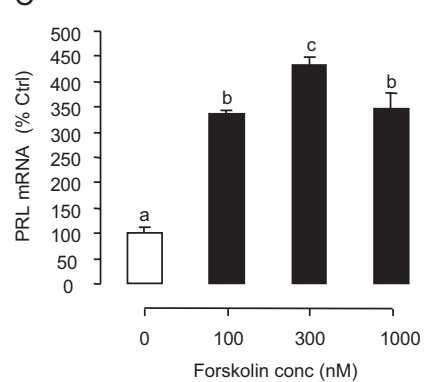

D

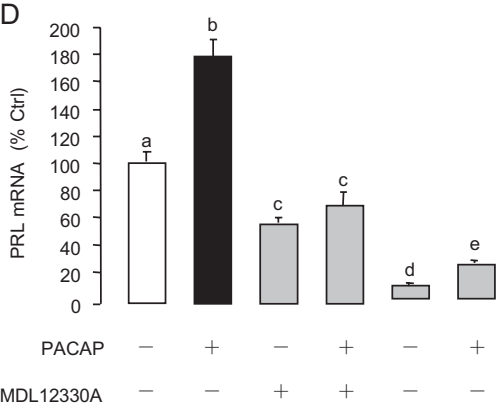

Figure 3

Functional role of AC/CAMP/PKA pathway in PACAP-induced prl mRNA expression in carp pituitary cells. (A) Effects of PACAP treatment on cAMP release, CAMP cell content, and total cAMP production in carp RPD cells. RPD cells enriched with lactotrophs were prepared from the carp pituitary as described in 'Materials and methods' section and challenged for $15 \mathrm{~min}$ with increasing doses of ovine $\operatorname{PACAP}_{38}(0.1-1000 \mathrm{nM})$. Culture medium and cellular contents were collected for CAMP measurements using a CAMP RIA. Samples from individual wells for cAMP release and cAMP cell content were pooled together to reconstitute the samples for total CAMP production. Activation of CAMP-dependent pathway on prl mRNA expression at pituitary level. Pituitary cells were treated for $48 \mathrm{~h}$ with increasing doses of (B) the CAMP analog cpt-cAMP and (C) the adenylate cyclase (AC) activator forskolin, respectively. Inhibition of CAMP-dependent pathway on PACAP-induced prl mRNA expression in carp pituitary cells. In this study, pituitary cells were challenged with ovine PACAP $38(100 \mathrm{nM}, 48 \mathrm{~h})$ in the presence of the AC inhibitor MDL12330A $(30 \mu \mathrm{M})$ or PKA blocker H89 (20 $\mu \mathrm{M})(\mathrm{D})$. Data presented are expressed as mean \pm S.E.M. $(N=4)$ and different letters denote a significant difference at $P<0.05$ (ANOVA followed by Fisher's LSD test).

$\mathrm{Ca}^{2+} / \mathrm{CaM}$-dependent cascades (Wong et al. 2005). To evaluate the possible role of $\mathrm{Ca}^{2+}$-dependent mechanisms in PACAP-induced prl gene expression, carp pituitary cells were preloaded with the $\mathrm{Ca}^{2+}$-sensitive dye Fura-2 to check for the effect of PACAP on [Ca $\left.{ }^{2+}\right]$ i levels in grass carp lactotrophs. As shown in Fig. 4A, ovine PACAP (10 nM) was effective in triggering a rapid and transient increase in $\left[\mathrm{Ca}^{2+}\right] \mathrm{i}$ in carp pituitary cells. Using immunostaining with PRL antiserum, some of the cells with $\mathrm{Ca}^{2+}$ responses were confirmed to be carp lactotrophs.

To unveil the functional role of $\left[\mathrm{Ca}^{2+}\right] \mathrm{i}$ in $\mathrm{prl}$ gene expression, carp pituitary cells were treated with increasing doses of the $\mathrm{Ca}^{2+}$ ionophore A23187 (1-100 nM, Fig. 4B) and VSCC activator Bay K8644 (1-100 nM, Fig. 4C), which are known to increase [Ca $\left.{ }^{2+}\right] \mathrm{i}$ via $\mathrm{Ca}^{2+}$ influx in live cells. In both cases, prl mRNA levels were found to be elevated in a dose-dependent manner after drug treatment. In contrast, both basal and PACAP-induced prl mRNA expression could be suppressed by removing [ $\left.\mathrm{Ca}^{2+}\right]$ e using a $\mathrm{Ca}^{2+}$-free culture medium (Fig. 4D). Furthermore, the stimulatory effect of PACAP on prl gene expression was also blocked by inactivating L-type VSCC using the inhibitor nifedipine $(10 \mu \mathrm{M})$ or verapamil $(5 \mu \mathrm{M})$ (Fig. $4 \mathrm{E})$.

To shed light on the downstream signaling that occurs after $\mathrm{Ca}^{2+}$ rise, the role of CaM/CaMK cascade in PACAPinduced prl gene expression was also tested. As shown in Fig. 5A, treatment with ovine PACAP $(0.1-100 \mathrm{nM})$ could elevate the cellular content of CaM in carp RPD cells in a dose-related fashion without corresponding changes in $\beta$-actin level. In parallel experiments with carp pituitary cells, both basal as well as PACAP (100 nM)-induced $p r l$ mRNA expression could be suppressed by co-treatment with the CaM antagonist calmidazolium $(1 \mu \mathrm{M}$, Fig. 5B). Similarly, the stimulatory effect of PACAP on prl gene expression was also sensitive to the blockade with the 
A
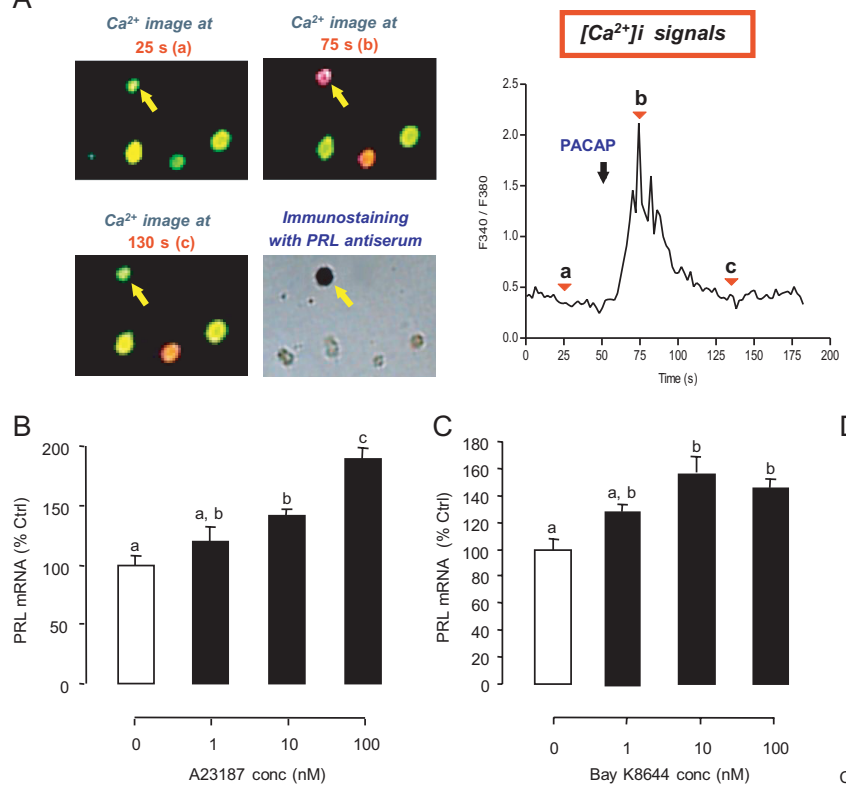

D

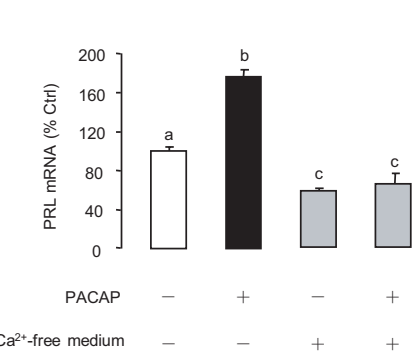

E

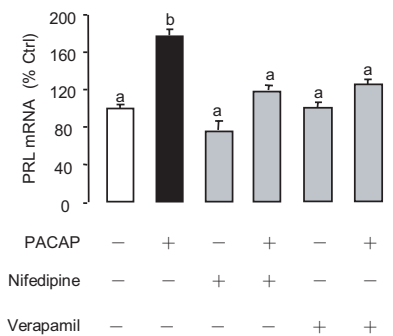

Figure 4

Functional role of $\mathrm{Ca}^{2+-d e p e n d e n t ~ p a t h w a y ~ i n ~ P A C A P-i n d u c e d ~ p r l ~ m R N A ~ e x p r e s s i o n ~ i n ~ c a r p ~ p i t u i t a r y ~ c e l l s . ~(A) ~ E f f e c t ~ o f ~ P A C A P ~ o n ~ i n t r a c e l l u l a r ~ C a 2+~([C a 2+] ~}$ i) signals in carp lactotrophs ('Prl cells'). Pituitary cells were preloaded with the $\mathrm{Ca}^{2+-s e n s i t i v e ~ d y e ~ F u r a-2 ~ a n d ~ c h a l l e n g e d ~ w i t h ~ o v i n e ~ P A C A P ~} 38(1 \mu \mathrm{M})$ as described in 'Materials and methods' section. After that, post facto identification of Prl cells on cell-locate coverslip was conducted by immunostaining with Prl antiserum and mapped with the responsive cells with $\mathrm{Ca}^{2+}$ signals after PACAP treatment. Effect of increasing [Ca ${ }^{2+}$ ]i on prl mRNA expression at pituitary level. Pituitary cells were treated for $48 \mathrm{~h}$ with increasing doses of (B) Ca2+ ionophore A23187 or (C) L-type VSCC activator Bay K8644. Inhibiting extracellular $\mathrm{Ca}^{2+}$ entry on $\mathrm{pr}$ mRNA expression in carp pituitary cells. In this study, pituitary cells were treated with ovine PACAP ${ }_{38}(1 \mu \mathrm{M}, 48 \mathrm{~h})$ in (D) Ca2+-free medium (with $0.1 \mathrm{mM}$ EGTA) or (E) with the L-type VSCC blocker nifedipine (10 mM) or verapamil (5 mM). After treatment, total RNA was isolated and subjected to real-time PCR for prl mRNA measurement. Data presented are expressed as mean \pm S.E.M. ( $N=4$ ) and different letters denote a significant difference at $P<0.05$ (ANOVA followed by Fisher's LSD test).

CaMK-II inhibitors KN62 (5 $\mu \mathrm{M}$, Fig. 5C) and KN93 (5 $\mu \mathrm{M}$, Fig. 5D), respectively.

In mammals, PAC1 receptor activation can also increase $\left[\mathrm{Ca}^{2+}\right] \mathrm{i}$ by mobilization of intracellular $\mathrm{Ca}^{2+}$ stores via the PLC/IP 3 PKC pathway (Vaudry et al. 2009). In carp pituitary cells, both basal and PACAP (100 nM)induced prl mRNA expression were downregulated by co-treatment with the PLC inhibitor U73122 $(10 \mu \mathrm{M}$, Fig. 5E). Furthermore, the inhibitory effect of U73122 on PACAP-induced prl mRNA expression was also mimicked by the $\mathrm{IP}_{3}$ receptor inhibitor 2 -APB $(100 \mu \mathrm{M}$, Fig. $5 \mathrm{~F})$ or the $\mathrm{IP}_{3}$ antagonist XeC $(3 \mu \mathrm{M}$, Fig. $5 \mathrm{~F})$. In parallel experiments, the PKC activator TPA (10-1000 nM) could elevate prl mRNA levels in carp pituitary cells (Supplementary Fig. 1A, see section on supplementary data given at the end of this article), but co-treatment with the PKC inhibitor GF109203 $(1 \mu \mathrm{M}$, Supplementary Fig. 1B) or Calphostin C $(10 \mu \mathrm{M}$, data not shown) was not effective in blocking the PACAP induction of $\mathrm{prl}$ gene expression.

\section{Functional coupling of $\mathrm{Ca}^{2+-}$ dependent and CAMP- dependent pathways in PRL gene expression}

Given that PKA is known to trigger protein phosphorylation and subsequent activation of $\mathrm{Ca}^{2+}$ channels (Kamp \& Hell 2000), it raises the possibility that $\mathrm{Ca}^{2+} / \mathrm{CaM}$-dependent mechanisms may be acting downstream of cAMP/PKA pathway to mediate PACAPinduced $p r l$ gene expression. To test the hypothesis, the membrane-permeable cAMP analog cpt-cAMP was substituted for PACAP as the stimulant for cAMP-dependent pathway, and its effect on prl gene expression was examined with concurrent perturbation of $\mathrm{Ca}^{2+}$ entry or CaM/CaMK-II activation. Similar to our preceding studies, cpt-cAMP $(100 \mu \mathrm{M})$ treatment consistently elevated basal levels of prl mRNA in grass carp pituitary cells. This stimulatory action, however, could be inhibited/negated by removing [ $\left.\mathrm{Ca}^{2+}\right] \mathrm{e}$ with a $\mathrm{Ca}^{2+-f r e e ~ m e d i u m ~(F i g . ~ 6 A), ~ C a M ~ a n t a g o n i s m ~ w i t h ~}$ calmidazolium ( $1 \mu \mathrm{M}$, Fig. $6 \mathrm{C})$, or inactivating CaMK-II http://joe.endocrinology-journals.org DOI: 10.1530/JOE-16-0433
๑ 2017 Society for Endocrinology Printed in Great Britain 
A

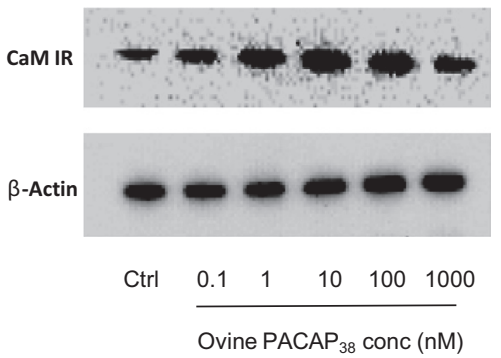

D

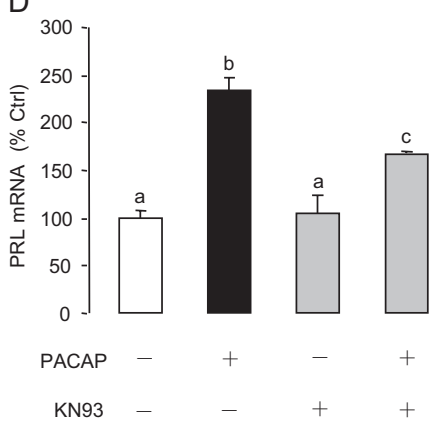

B

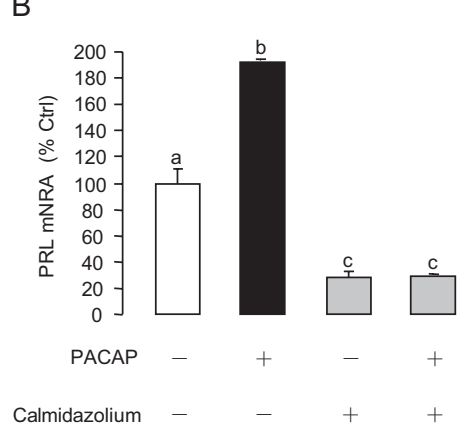

E

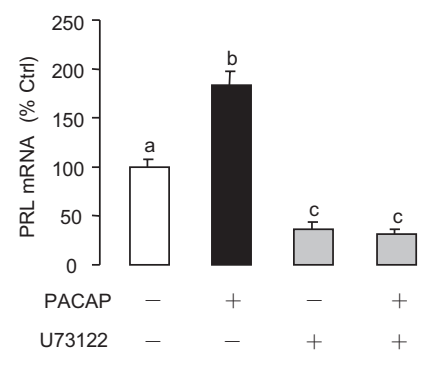

C

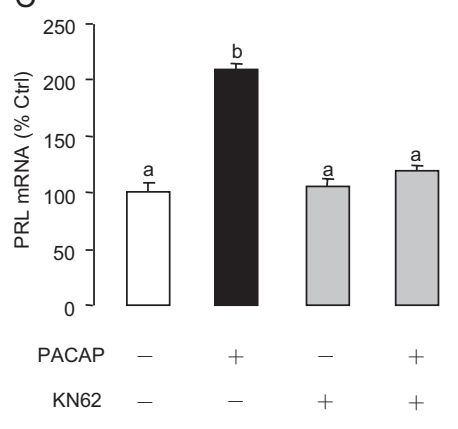

$\mathrm{F}$

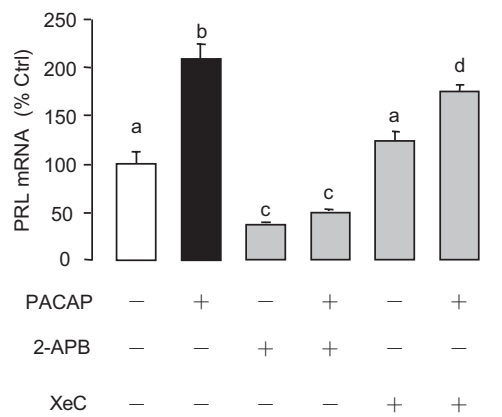

Figure $\mathbf{5}$

Functional role of CaM/CaMK-II cascades in PACAP-induced prl mRNA expression in carp pituitary cells. (A) Effect of PACAP on calmodulin (CaM) expression in grass carp RPD cells. RPD cells enriched with lactotrophs were prepared from the carp pituitary as described in 'Materials and methods' section and challenged for $48 \mathrm{~h}$ with increasing doses of ovine PACAP ${ }_{38}$. After that, cell lysate was prepared and used for Western blot detection of CaM immunoreactivity (CaM IR) using the antiserum for human CaM. Parallel blotting of $\beta$-actin expression was used as the internal control. Blockade of $\mathrm{CaM} / \mathrm{CaMK}-\mathrm{Il}$ cascades on PACAP-induced $\mathrm{prl}$ mRNA expression at the pituitary level. Carp pituitary cells were challenged with ovine PACAP ${ }_{38}$ (100 $\mathrm{nM}_{\text {, }}$ $48 \mathrm{~h}$ ) in the presence of the CaM antagonist calmidazolium (1 mM, B) or CaMK-II inhibitors KN62 (5 mM, C) and KN93 (5 mM, D), respectively. Functional role of PLC/IP ${ }_{3}$ cascade in PACAP-induced $\mathrm{prl}$ gene expression in carp pituitary cells. Pituitary cells were challenged with ovine PACAP ${ }_{38}(100 \mathrm{nM})$ for $48 \mathrm{~h}$ with co-treatment of $(E)$ the PLC inhibitor U73122 (10 mM) or (F) the inhibitors for $\mathrm{PP}_{3}$ action, including the $\mathrm{IP}_{3}$ receptor blocker $2-A P B(100 \mathrm{mM})$ and $\mathrm{IP}_{3}$ antagonist Xestospongin $\mathrm{C}(\mathrm{XeC}, 3 \mathrm{mM})$. After treatment, total RNA was isolated and subjected to real-time PCR for prl mRNA measurement. Data presented are expressed as mean \pm S.E.M. $(N=4)$ and different letters denote a significant difference at $P<0.05$ (ANOVA followed by Fisher's LSD test).

with KN62 (5 $\mu \mathrm{M}$, Fig. 6D). Interestingly, inhibiting VSCC with nifedipine $(10 \mu \mathrm{M}$, Fig. $6 \mathrm{~B})$ was not effective in blocking cpt-cAMP-induced prl mRNA expression. In parallel study, CaM immunoreactivity in RPD cells could be elevated by treatment with the AC activator forskolin (100nM) but not the PKC activator TPA (as negative control of the experiment) and this stimulatory effect could be blocked by inactivating PKA using the inhibitor H89 (20 $\mu$ M, Fig. 6E).

\section{Functional role of PI3K and MAPK cascades in PACAP- induced PRL gene expression}

In mammals, PACAP activation of PI3K and MAPK cascades have been reported, for example, in human neuroblastoma cells (Kojro et al. 2006). Therefore, the functional role of these pathways in PACAP-induced prl gene expression was also examined. In carp pituitary cells, PACAP induction (100 nM) consistently elevated basal level of prl mRNA and this stimulating effect was not affected by co-treatment with the $\mathrm{MEK}_{1 / 2}$ inhibitor U0126 $(10 \mu \mathrm{M}), \mathrm{P}_{38}{ }^{\text {MAPK }}$ inhibitor PD $169316(10 \mu \mathrm{M})$, or PI3K inhibitor Ly294002 (10 $\mu \mathrm{M})$ (Supplementary Fig. 2). In parallel experiments, however, PACAP (100 nM)induced prl mRNA expression was totally abolished by simultaneous treatment with the JNK inhibitor (L)-JNKI $1(10 \mu \mathrm{M}$, Fig. 7A) or SP600125 $(10 \mu \mathrm{M}$, Fig. 7B). To test the functional coupling of JNK- and cAMP-dependent mechanisms in PACAP-induced prl gene expression, PACAP was replaced by cpt-cAMP $(100 \mu \mathrm{M})$ as the stimulant for $p r l$ gene expression and the stimulatory effect of cpt-cAMP was examined in the presence of JNK inhibitors. In this case, prl mRNA expression induced by cpt-cAMP was partially blocked by the JNK inhibitor (L)-JNKI $1(10 \mu \mathrm{M}$, Fig. 7C) and SP600125 (10 $\mathrm{M}$, Fig. 7D), respectively. 
A

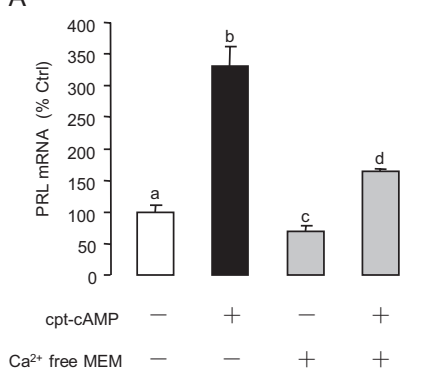

B

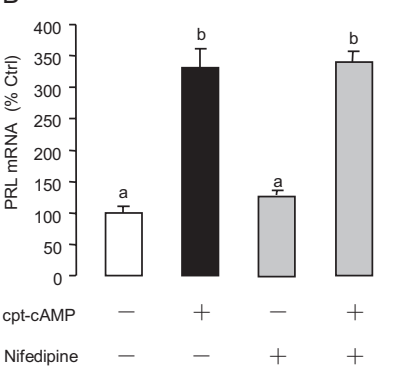

C

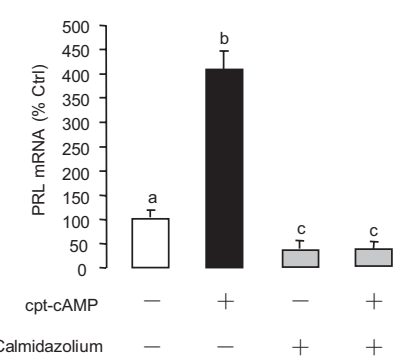

D

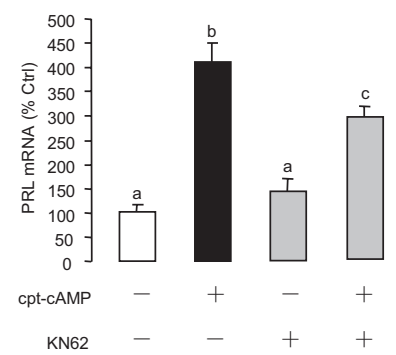

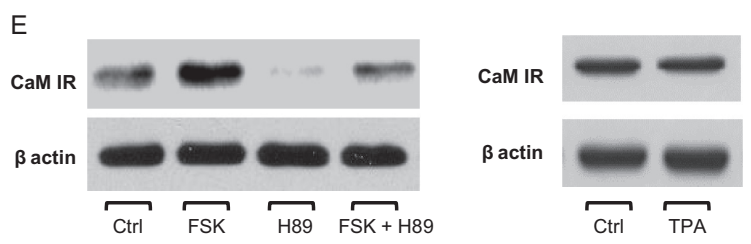

Figure 6

Functional coupling of CAMP- and $\mathrm{Ca}^{2+} / \mathrm{CaM}$-dependent pathways in prl mRNA expression in carp pituitary cells. Pituitary cells were treated with the CAMP analog cpt-CAMP $(100 \mu \mathrm{M}, 48 \mathrm{~h})$ in (A) Ca2+-free medium (with $0.1 \mathrm{mM} \mathrm{EGTA)}$ or with co-treatment of (B) VSCC blocker nifedipine (10 $\mu \mathrm{M})$, (C) CaM antagonist calmidazolium $(10 \mu \mathrm{M})$, or (D) CaMK-II inhibitor KN62 $(100 \mu \mathrm{M})$. In parallel experiments, the effect of the AC activator forskolin (100 nM, $48 \mathrm{~h})$ on CaM expression was tested in grass carp RPD cells in the presence or absence of the PKA inhibitor H89 (20 $\mu$ M, E). Parallel treatment with the PKC activator TPA $(1 \mu \mathrm{M})$ was used as the negative control for the study. After treatment, cell lysate was prepared for Western blot detection of CaM immunoreactivity (CaM IR). Except for the results of Western blot, data presented are expressed as mean \pm S.E.M. $(N=4)$ and different letters denote a significant difference at $P<0.05$ (ANOVA followed by Fisher's LSD test).

\section{Discussion}

Within the CNS, PACAP can not only act as a neurotransmitter (Fahrenkrug 2006) and neurotrophic factor (Vallejo \& Vallejo 2002, Botia et al. 2007), but also serve as a hypophysiotropic factor with pituitary functions (Wong et al. 2000). This idea is supported by the findings that (1) PACAP cell bodies are located within the hypothalamus (Hannibal 2002, Durr et al. 2007); (2) PACAP nerve fibers can be identified in the external zone of the median eminence (Piggins et al. 1996); (3) PACAP immunoreactivity can be detected in the hypophyseal portal blood (Dow et al. 1994); and (4) under certain conditions, PACAP can induce pituitary hormone secretion, for example, Lh, Gh and Prl (Murakami et al. 2001, Kanasaki et al. 2013). In grass carp, PACAP nerve fibers can be located in the anterior pituitary overlapping with the distribution of somatotrophs and lactotrophs (Wong et al. 2005). The close proximity of PACAP fibers with carp lactotrophs also provides the anatomical substrate for Prl regulation by PACAP in the carp pituitary. In the present study, the functional role of PACAP in Prl regulation in grass carp was confirmed by the demonstration that PACAP of both mammalian
A

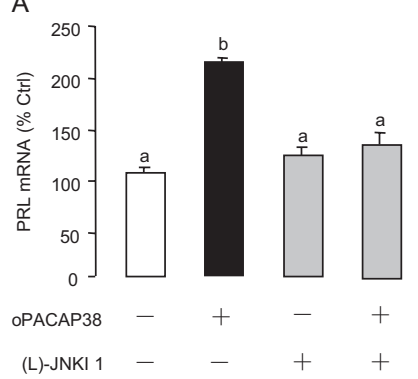

B

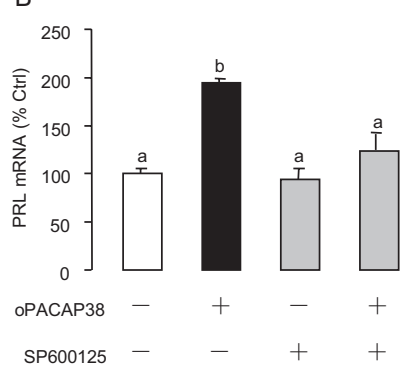

C

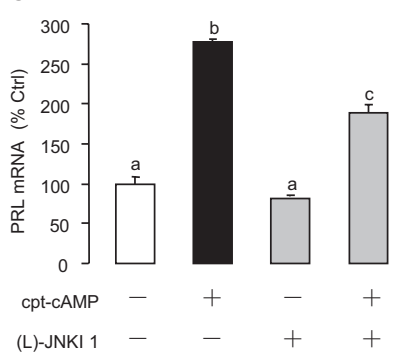

D

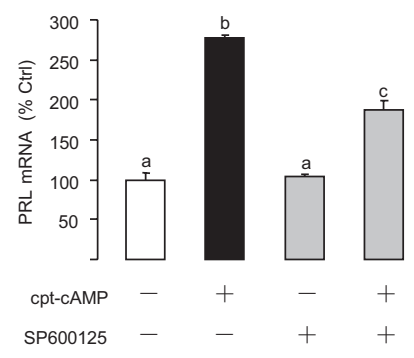

Figure 7

Functional role of JNK in PACAP-induced prl mRNA expression in carp pituitary cells. Pituitary cells were challenged with ovine PACAP ${ }_{38}(100 \mathrm{nM}, 48 \mathrm{~h})$ with co-treatment of the JNK inhibitor (L)-JNKI $1(10 \mu \mathrm{M}, \mathrm{A})$ or SP600125 $(10 \mu \mathrm{M}, \mathrm{B})$. To examine the functional coupling of JNK with cAMP pathway, the effect of cpt-cAMP $(100 \mu \mathrm{M}, 48 \mathrm{~h})$ on prl mRNA expression was also tested in parallel experiments in the presence of (L)-JNKI 1 (10 $\mu \mathrm{M}, \mathrm{C})$ and SP600125 $(10 \mu \mathrm{M}, \mathrm{D})$, respectively. After drug treatment, total RNA was isolated and subjected to real-time PCR for prl mRNA measurement. Data presented are expressed as mean \pm S.E.M. $(N=4)$ and different letters denote a significant difference at $P<0.05$ (ANOVA followed by Fisher's LSD test).

http://joe.endocrinology-journals.org DOI: $10.1530 / \mathrm{JOE}-16-0433$ (c) 2017 Society for Endocrinology Printed in Great Britain
Published by Bioscientifica Ltd. 
and fish origin could induce Prl release, Prl production and prl mRNA expression via direct action at pituitary cell level. The stimulatory actions of PACAP were noted in the nanomolar dose range and similar levels of VIP were not effective in mimicking PACAP stimulation on Prl expression. The specificity for PACAP over VIP in terms of efficacy/potency of Prl induction was consistent with the pharmacological properties of mammalian PAC1 receptor, which is known to have a high affinity for PACAP but not VIP binding (Murakami et al. 2001). Of note, expression of PAC1 receptor has been reported in the pituitary of fish models, for example, in goldfish (Kwok et al. 2006), and mediates the effects of PACAP on GH and somatolactin secretion/gene expression (Wong et al. 2005, Azuma et al. 2013). In grass carp pituitary cells, PACAP-induced prl mRNA expression could be blocked by the PACAP antagonist PACAP ${ }_{6-38}$ but not VIP antagonist (4-Cl-D-Phe', Leu ${ }^{17}$ )VIP. In parallel study with RT-PCR coupled to LCM isolation of immuno-identified pituitary cells, PAC1 receptor was also detected in carp lactotrophs. These findings, taken together, indicate that PAC1 receptor is involved in PRL regulation by PACAP in the carp pituitary. To our knowledge, our study represents the first report to provide evidence that PACAP can induce Prl production via upregulation of prl gene expression through activation of pituitary PAC1 receptors.

In mammals, functional coupling of PAC1 receptor with cAMP- and $\mathrm{Ca}^{2+}$-dependent signaling mechanisms is well-documented (Dickson \& Finlayson 2009). In lactotroph cell lines, for example, $\mathrm{GH}_{3}$ cells, PACAP has been previously shown to trigger prl gene expression via cAMP-dependent (Mijiddorj et al. 2011) and cAMPindependent signaling pathways (Coleman \& Bancroft 1993). Apparently, the cAMP/PKA pathway is also involved in PACAP-induced prl gene expression in the carp pituitary, as PACAP treatment could trigger cAMP production in RPD cells enriched with carp lactotrophs. Furthermore, PACAP-induced prl mRNA expression could be mimicked by activating AC activity with forskolin or increasing the functional level of cAMP with cpt-cAMP, whereas the stimulatory action of PACAP was blocked by inhibiting AC with MDL12330A and inactivating PKA with H89, respectively. These results strongly suggest that the AC/cAMP/PKA pathway is involved in PACAPinduced $p r l$ gene expression, probably via PAC1 receptor activation in lactotrophs. In our previous studies in carp pituitary cells, PACAP was shown to elevate [ $\left.\mathrm{Ca}^{2+}\right]$ i signals, presumably by activation of VSCC and/or mobilization of intracellular $\mathrm{Ca}^{2+}$ stores (Wong et al. 2005). Given that induction of $\mathrm{Ca}^{2+}$ entry in pituitary lactotrophs is known to induce PRL release, for example, in rat (Andric et al. 2005), it is possible that $\mathrm{Ca}^{2+}$-dependent mechanisms are also involved in PACAP-induced prl gene expression in the carp model. This hypothesis is supported by the findings that PACAP induction could trigger a rapid and transient rise in $\left[\mathrm{Ca}^{2+}\right] \mathrm{i}$ in carp lactotrophs and prl gene expression induced by PACAP was mimicked by inducing $\left[\mathrm{Ca}^{2+}\right]$ e entry with $\mathrm{Ca}^{2+}$ ionophore A23187 or activating VSCC with Bay K8644. Furthermore, PACAP-induced prl mRNA expression in carp pituitary cells was totally abolished by removing $\left[\mathrm{Ca}^{2+}\right]$ e using $\mathrm{Ca}^{2+}$-free medium or inhibiting VSCC by nifedipine and verapamil. In fish models, for example, goldfish (Huo et al. 2004), protein expression of CaM can be upregulated at pituitary level by PACAP treatment, and in our study, similar finding was also observed in grass carp RPD cells enriched with lactotrophs. In addition, PACAP-induced prl mRNA expression in carp pituitary cells could be blocked by CaM antagonism with calmidazolium or CaMK-II inactivation by $\mathrm{KN} 62 / \mathrm{KN} 93$. These results imply that $\mathrm{Ca}^{2+}$ entry via VSCC and subsequent activation of CaM and CaMK-II may be involved in PACAP induction of prl gene expression.

Of note, the $\mathrm{Ca}^{2+}$-dependent mechanisms may be functionally coupled with the cAMP pathway in Prl regulation in carp model, as the stimulatory effect of cAMP analog cpt-cAMP on prl mRNA expression in carp pituitary cells was also sensitive to the inhibition by $\mathrm{Ca}^{2+}$-free medium, CaM antagonism, and CaMK-II inactivation. Meanwhile, forskolin treatment could mimic PACAP induction of CaM expression and this stimulatory effect was blocked by PKA inactivation with H89. Presumably, the coupling between $\mathrm{Ca}^{2+}$ dependent CaMK-II activation and cAMP-dependent pathway is mediated by PKA-dependent activation of $\mathrm{CaM}$ expression. However, cpt-cAMP-induced prl gene expression was not affected by VSCC blockade with nifedipine, suggesting that PACAP may act through cAMP-independent mechanisms to trigger VSCC activation for $\left[\mathrm{Ca}^{2+}\right]$ e entry at pituitary cell level. Previous studies have shown that both L-type and T-type VSCC are expressed in PRL-secreting pituitary cells, for example, in rat (Lewis et al. 1988). Therefore, we do not exclude the possibility that $\mathrm{Ca}^{2+}$ channels other than L-type VSCC (i.e., target for nifedipine) may be involved in PAC1 activation. It is worth mentioning that treatment with $\mathrm{Ca}^{2+}$-free medium not only can remove $\left[\mathrm{Ca}^{2+}\right] \mathrm{e}$ but also deplete intracellular $\mathrm{Ca}^{2+}$ stores in cell culture, the inhibitory effect of $\mathrm{Ca}^{2+}$-free medium on PACAP or 
cpt-cAMP induction may also involve an intracellular $\mathrm{Ca}^{2+}$ component. In carp pituitary cells, PAC1 receptor activation can induce somatolactin gene expression via the PLC/IP 3 /PKC pathway (Jiang et al. 2008a,b). In the present study, PACAP-induced prl mRNA expression was blocked by inhibiting PLC with U73122, $\mathrm{IP}_{3}$ antagonism with $\mathrm{XeC}$, or inactivating $\mathrm{IP}_{3}$ receptor using 2-APB. Although PKC activation by TPA could mimic PACAP induction of $p r l$ gene expression, PKC inactivation by GF109203 or Calphostin C did not alter the stimulatory effect of PACAP. These findings indicate that the PLC/IP 3 pathway (but without the PKC component) is involved in PACAP stimulation of $p r l$ gene expression in the carp pituitary. Given that $\mathrm{IP}_{3}$ receptors are intracellular $\mathrm{Ca}^{2+}$ channels responsible for $\mathrm{Ca}^{2+}$ release from $\mathrm{IP}_{3}$-sensitive $\left[\mathrm{Ca}^{2+}\right]$ i stores (Foskett et al. 2007), the inhibitory effects observed during $\mathrm{IP}_{3}$ antagonism/ $/ \mathrm{IP}_{3}$ receptor blockade may imply that $\mathrm{IP}_{3}$-mediated $\left[\mathrm{Ca}^{2+}\right] \mathrm{i}$ mobilization may also contribute to PACAP-induced $\mathrm{prl}$ gene expression. To our knowledge, the functional coupling of cAMP with $\mathrm{CaM}$ expression and $\mathrm{Ca}^{2+}$ signaling in prl gene expression has not been reported previously in mammalian models.

In mammals, PAC-I receptors are known to couple with MAPK signaling via cAMP-dependent (Monaghan et al. 2008) and/or independent pathways (Hamelink et al. 2002, Vaudry et al. 2003). In addition, PACAP activation of the PI3K/Akt pathway via the PAC1/VPAC2 receptors has also been reported, for example, in rat schwannoma cells (Castorina et al. 2014). In grass carp pituitary cells, however, PACAP-induced prl mRNA expression was not sensitive to $\mathrm{MEK}_{1 / 2}$ inhibition by U0126, $\mathrm{P}_{38}$ MAPK blockade with PD16316, or PI3K inactivation using Ly294002. Interestingly, the stimulatory effect of PACAP was abolished using the JNK inhibitors (L)-JNKI 1 and SP600125, implying that JNK (not $\mathrm{P}_{38}{ }^{\text {MAPK }}$ or $\mathrm{MEK}_{1 / 2} /$ $\mathrm{ERK}_{1 / 2}$ ) of the MAPK cascades, but not PI3K/Akt pathway, is involved in PACAP-induced prl gene expression. Since prl mRNA expression in carp pituitary cells induced by cpt-cAMP was also sensitive to the blockade by (L)-JNKI 1 and SP600125, it is likely that a functional cross talk between cAMP-dependent cascade and MAPK pathway (via JNK activation) also plays a role in PRL regulation by PACAP in carp lactotrophs.

In summary, using grass carp pituitary cells as a model, we have demonstrated for the first time that PACAP stimulates Prl production at the pituitary level via upregulation of $p r l$ gene expression through PAC1 receptor activation. This stimulatory effect is mediated through functional coupling of cAMP-, $\mathrm{Ca}^{2+} / \mathrm{CaM}-$,

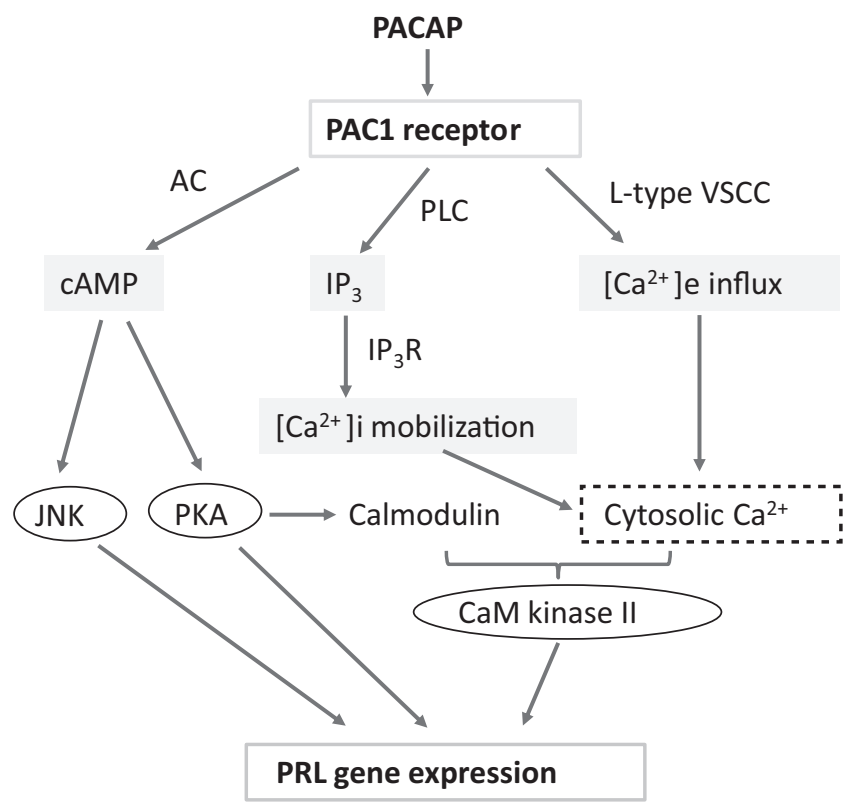

Figure 8

Working model for signal transduction mechanisms involved in PACAP stimulation of prl gene expression via PAC1 receptor in grass carp lactotrophs.

and MAPK-dependent cascades, presumably within the carp lactotrophs. In our working model (Fig. 8), PACAP activation of PAC1 receptor expressed in lactotrophs can activate PRL gene expression via the AC/cAMP/ PKA pathway, which may also play a role in elevating $\mathrm{CaM}$ expression at cellular level. Meanwhile, PAC1 receptor activation can also trigger $\left[\mathrm{Ca}^{2+}\right]$ i signals via two separate mechanisms, including (i) $\mathrm{Ca}^{2+}$ influx through activation of L-type VSCC and (ii) $\left[\mathrm{Ca}^{2+}\right] \mathrm{i}$ mobilization from intracellular stores by activation of the PLC/IP pathway. Although PKC activation can also induce prl gene expression, it is not involved in prl regulation by PACAP. In our cell model, the parallel rises in $\left[\mathrm{Ca}^{2+}\right]$ $\mathrm{i}$ and $\mathrm{CaM}$ expression presumably can trigger prl gene expression through CaMK-II activation. Other than the functional coupling with $\mathrm{Ca}^{2+} / \mathrm{CaM}$-dependent pathway, cAMP production caused by PACAP can also induce a 'cross-activation' of JNK, which may also contribute to the stimulation on prl gene expression via PAC1 receptor. Our study, taken together, provides evidence for a comprehensive model with new information on receptor specificity and signal transduction for $p r l$ regulation by PACAP in a fish model. Our findings also shed light on the role of PACAP as a hypophysiotropic factor with stimulatory actions on Prl synthesis and secretion at the pituitary level in carp species. 


\section{Supplementary data}

This is linked to the online version of the paper at http://dx.doi.org/10.1530/ JOE-16-0433.

\section{Declaration of interest}

The authors declare that there is no conflict of interest that could be perceived as prejudicing the impartiality of the research reported.

\section{Funding}

The project was supported by GRF grants $(17128215,781113$, and 780312) and NSFC/RGC joint grant (N_HKU 732/12) from Research Grant Council (HK), HMRF Grant (13142591) from Food and Health Bureau (HKSAR) (to A O L W), and NSFC grant (31660335) from National Natural Science Foundation of China (to $C L$ ). Financial support to $C L$ and $J X$ from the School of Biological Sciences (University of Hong Kong) is also acknowledged.

\section{Author contribution statement}

$C \mathrm{~L}$ and $\mathrm{J} \mathrm{X}$ were responsible for grass carp pituitary cell preparation and pharmacological studies to decipher the receptor specificity and signal transduction mechanisms involved in PRL regulation by PACAP; $M H_{,} L Z$, and $\mathrm{T} \mathrm{H}$ took care of $\mathrm{Ca}^{2+}$ imaging, CAMP experiments, and LCM capture of carp lactotrophs for RT-PCR of PAC-I receptor; and A O L W was the PI and grant holder, and worked with $C L$ and $Z B$ on manuscript preparation and revision.

\section{References}

Andric SA, Zivadinovic D, Gonzalez-Iglesias AE, Lachowicz A, Tomic M \& Stojilkovic SS 2005 Endothelin-induced, long lasting, and $\mathrm{Ca} 2+$ influx-independent blockade of intrinsic secretion in pituitary cells by Gz subunits. Journal of Biological Chemistry $28026896-26903$. (doi:10.1074/jbc.M502226200)

Azuma M, Suzuki T, Mochida H, Tanaka S \& Matsuda K 2013 Pituitary adenylate cyclase-activating polypeptide (PACAP) stimulates release of somatolactin (SL)-alpha and SL-beta from cultured goldfish pituitary cells via the PAC(1) receptor-signaling pathway, and affects the expression of SL-alpha and SL-beta mRNAs. Peptides 43 40-47. (doi:10.1016/j.peptides.2013.02.006)

Benter S, Leonhardt S, Wuttke W \& Jarry H 1995 Paracrine cell to cell interactions determine the effects of pituitary adenylate cyclase activating polypeptide (PACAP) on in vitro prolactin release from rat pituitary cells. Experimental and Clinical Endocrinology and Diabetes 103 386-390. (doi:10.1055/s-0029-1211383)

Botia B, Basille M, Allais A, Raoult E, Falluel-Morel A, Galas L, Jolivel V, Wurtz O, Komuro H, Fournier A, et al. 2007 Neurotrophic effects of PACAP in the cerebellar cortex. Peptides 28 1746-1752. (doi:10.1016/j. peptides.2007.04.013)

Castorina A, Scuderi S, D'Amico AG, Drago F \& D'Agata V 2014 PACAP and VIP increase the expression of myelin-related proteins in rat schwannoma cells: Involvement of PAC1/VPAC2 receptor-mediated activation of PI3K/Akt signaling pathways. Experimental Cell Research 322 108-121. (doi:10.1016/j.yexcr.2013.11.003)

Christian HC, Chapman LP \& Morris JF 2007 Thyrotrophinreleasing hormone, vasoactive intestinal peptide, prolactin- releasing peptide and dopamine regulation of prolactin secretion by different lactotroph morphological subtypes in the rat. Journal of Neuroendocrinology 19 605-613. (doi:10.1111/j.13652826.2007.01567.x)

Coleman DT \& Bancroft C 1993 Pituitary adenylate cyclase-activating polypeptide stimulates prolactin gene expression in a rat pituitary cell line. Endocrinology 133 2736-2742. (doi:10.1210/ en.133.6.2736)

Dickson L \& Finlayson K 2009 VPAC and PAC receptors: from ligands to function. Pharmacology and Therapeutics 121 294-316. (doi:10.1016/j. pharmthera.2008.11.006)

Dow RC, Bennie J \& Fink G 1994 Pituitary adenylate cyclase-activating peptide-38 (PACAP)-38 is released into hypophysial portal blood in the normal male and female rat. Journal of Endocrinology 142 R1-R4. (doi:10.1677/joe.0.142R001)

Durr K, Norsted E, Gomuc B, Suarez E, Hannibal J \& Meister B 2007 Presence of pituitary adenylate cyclase-activating polypeptide (PACAP) defines a subpopulation of hypothalamic POMC neurons. Brain Research 1186 203-211. (doi:10.1016/j.brainres.2007.10.015)

Fahrenkrug J 2006 PACAP: a multifaceted neuropeptide. Chronobiology International 23 53-61. (doi:10.1080/07420520500464569)

Foskett JK, White C, Cheung KH \& Mak DO 2007 Inositol trisphosphate receptor $\mathrm{Ca}^{2+}$ release channels. Physiological Reviews 87 593-658. (doi:10.1152/physrev.00035.2006)

Harmar AJ, Fahrenkrug J, Gozes I, Laburthe M, May V, Pisegna JR, Vaudry H, Waschek JA \& Said SI 2012 Pharmacology and functions of receptors for vasoactive intestinal peptide and pituitary adenylate cyclase-activating polypeptide: IUPAR review I. British Journal of Pharmacology 166 4-17. (doi:10.1111/j.1476-5381.2012.01871.x)

Hart GR, Gowing H \& Burrin JM 1992 Effects of a novel hypothalamic peptide, pituitary adenylate cyclase-activating polypeptide, on pituitary hormone release in rats. Journal of Endocrinology 134 33-41. (doi:10.1677/joe.0.1340033)

Hamelink C, Lee HW, Chen Y, Grimaldi M \& Eiden LE 2002 Coincident elevation of cAMP and calcium influx by PACAP-27 synergistically regulates vasoactive intestinal polypeptide gene transcription through a novel PKA-independent signaling pathway. Journal of Neuroscience 22 5310-5320.

Hannibal J 2002 Pituitary adenylate cyclase-activating peptide in the rat central nervous system: an immunohistochemical and in situ hybridization study. Journal of Comparative Neurology 453 389-417. (doi:10.1002/cne.10418)

Huo L, Lee EK, Leung PC \& Wong AO 2004 Goldfish calmodulin: molecular cloning, tissue distribution, and regulation of transcript expression in goldfish pituitary cells. Endocrinology 145 5056-5067. (doi:10.1210/en.2004-0584)

Jarry H, Leonhardt S, Schmidt WE, Creutzfeldt W \& Wuttke W 1992 Constrasting effects of pituitary adenylate cyclase-activating polypeptide on in vivo and in vitro prolactin and growth hormone release in male rats. Life Science $\mathbf{5 1} 823-830$. (doi:10.1016/00243205(92)90609-S)

Jiang Q, He M, Wang X \& Wong AO 2008a Grass carp somatolactin: II. Pharmacological study on postreceptor signaling mechanisms for PACAP-induced somatolactin $\alpha$ and $\beta$ gene expression. American Journal of Physiology: Endocrinology and Metabolism 295 E477-E490. (doi:10.1152/ajpendo.90386.2008)

Jiang Q, Ko WK, Lerner EA, Chan KM \& Wong AO 2008b Grass carp somatolactin: I. Evidence for PACAP induction of somatolactin $\alpha$ and $\beta$ gene expression via activation of pituitary PAC-I receptors. American Journal of Physiology: Endocrinology and Metabolism 295 E463-E476. (doi:10.1152/ajpendo.90385.2008)

Kamp TJ \& Hell JW 2000 Regulation of cardiac L-type calcium channels by protein kinase A and protein kinase C. Circulation Research $\mathbf{8 7}$ 1095-1102. (doi:10.1161/01.RES.87.12.1095)

Kanasaki H, Purwana IN \& Miyazaki K 2013 Possible role of PACAP and its PAC1 receptor in the differential regulation of pituitary $\mathrm{LH} \beta$ - and

Published by Bioscientifica Ltd. 
FSH $\beta$-subunit gene expression by pulsatile GnRH stimulation. Biology of Reproduction 88 35. (doi:10.1095/biolreprod.112.105601)

Kojro E, Postina R, Buro C, Meiringer C, Gehrig-Burger K \& Fahrenholz F 2006 The neuropeptide PACAP promotes the alpha-secretase pathway for processing the Alzheimer amyloid precursor protein. FASEB Journal 20 512-514. (doi:10.1096/fj.05-4812fje)

Kwok YY, Chu JY, Vaudry H, Yon L, Anouar Y \& Chow BK 2006 Cloning and characterization of a PAC1 receptor hop-1 splice variant in goldfish (Carassius auratus). General and Comparative Endocrinology 145 188-196. (doi:10.1016/j.ygcen.2005.08.011)

Lewis DL, Goodman MB, St John PA \& Barker JL 1988 Calcium currents and fura-2 signals in fluorescence-activated cell sorted lactotrophs and somatotrophs of rat anterior pituitary. Endocrinology 123 611-621. (doi:10.1210/endo-123-1-611)

Lin C, Jiang X, Hu G, Ko WK \& Wong AO 2015 Grass carp prolactin: molecular cloning, tissue expression, intrapituitary autoregulation by prolactin and paracrine regulation by growth hormone and luteinizing hormone. Molecular and Cellular Endocrinology 399 267-283. (doi:10.1016/j.mce.2014.10.010)

Matsuda K, Nejigaki Y, Satoh M, Shimaura C, Tanaka M, Kawamoto K, Uchiyama M, Kawauchi H, Shioda S \& Takahashi A 2008 Effect of pituitary adenylate cyclase-activating polypeptide on prolactin and somatolactin release from the goldfish pituitary in vitro. Regulatory Peptides 145 72-79. (doi:10.1016/j.regpep.2007.08.018)

Mijiddorj T, Kanasaki H, Purwana IN, Oride A \& Miyazaki K 2011 Stimulatory effect of pituitary adenylate-cyclase activating polypeptide and its PACAP type I receptor on prolactin synthesis in rat pituitary somatolactotroph GH3 cells. Molecular and Cellular Endocrinology 339 172-179. (doi:10.1016/j.mce.2011.04.010)

Mijiddorj T, Kanasaki H, Unurjargal S, Oride A, Purwana I \& Miyazaki K 2013 Prolonged stimulation with thyrotropin-releasing hormone and pituitary adenylate cyclase-activating polypeptide desensitize their functions in prolactin-producing GH3 cells. Molecular and Cellular Endocrinology 365 139-145. (doi:10.1016/j.mce.2012.10.006)

Miyata A, Arimura A, Dahl RR, Minamino N, Uehara A, Jiang L, Culler MD \& Coy DH 1989 Isolation of a novel 38 residuehypothalamic polypeptide which stimulates adenylate cyclase in pituitary cells. Biochemical and Biophysical Research Communications 164 567-574. (doi:10.1016/0006-291X(89)91757-9)

Miyata A, Jiang L, Dahl RD, Kitada C, Kubo K, Fujino M, Minamino N \& Arimura A 1990 Isolation of a neuropeptide corresponding to the N-terminal 27 residues of the pituitary adenylate cyclase activating polypeptide with 38 residues (PACAP38). Biochemical and Biophysical Research Communications 170 643-648. (doi:10.1016/0006291X(90)92140-U)

Monaghan TK, Mackenzie CJ, Plevin R \& Lutz EM 2008 PACAP-38 induces neuronal differentiation of human SH-SY5Y neuroblastoma cells via cAMP-mediated activation of ERK and p38 MAP kinases. Journal of Neurochemistry 104 74-88. (doi:10.1111/j.14714159.2007.05018.x)

Moody TW, Ito T, Osefo N \& Jensen RT 2011 VIP and PACAP: Recent insights into their functions/roles in physiology and disease from molecular and genetic studies. Current Opinion in Endocrinology, Diabetes and Obesity 18 61-67. (doi:10.1097/ MED.0b013e328342568a)

Murakami Y, Koshimura K, Yamauchi K, Nishiki M, Tanaka J \& Kato Y 2001 Roles and mechanisms of action of pituitary adenylate cyclase-activating polypeptide (PACAP) in growth hormone and prolactin secretion. Endocrine Journal 48 123-132. (doi:10.1507/ endocrj.48.123)

Piggins HD, Stamp JA, Burns J, Rusak B \& Semba K 1996 Distribution of pituitary adenylate cyclase activating polypeptide (PACAP) immunoreactivity in the hypothalamus and extended amygdala of the rat. Journal of Comparative Neurology 376 278-294. (doi:10.1002/ (SICI)1096-9861(19961209)376:2<278::AID-CNE9>3.0.CO;2-0)
Sawangjaroen K \& Curlewis JD 1994 Effects of pituitary adenylate cyclase-activating polypeptide and vasoactive intestinal polypeptide on prolactin, luteinizing hormone and growth hormone secretion in the ewe. Journal of Neuroendocrinology 6 545-555. (doi:10.1111/j.1365-2826.1994.tb00618.x)

Shu Y, Lou Q, Dai Z, Dai X, He J, Hu W \& Yin Z 2016 The basal function of teleost prolactin as a key regulator on ion uptake identified with zebrafish knockout models. Scientific Reports 6 18597. (doi:10.1038/ srep18597)

Sze KH, Zhou H, Yang Y, He M, Jiang Y \& Wong AO 2007 Pituitary adenylate cyclase-activating polypeptide (PACAP) as a growth hormone (GH)-releasing factor in grass carp: II. Solution structure of a brain-specific PACAP by nuclear magnetic resonance spectroscopy and functional studies on GH release and gene expression. Endocrinology 148 5042-5059. (doi:10.1210/en.2007-0576)

Tohei A, Ikeda M, Hokao R \& Shinoda M 2009 The different effects of i.c.v. injection of pituitary adenylate cyclase activating polypeptide (PACAP) on prolactin secretion in adult male and lactating rats. Experimental Animals 58 489-495. (doi:10.1538/expanim.58.489)

Vallejo I \& Vallejo M 2002 Pituitary adenylate cyclase-activating polypeptide induces astrocyte differentiation of precursor cells from developing cerebral cortex. Molecular and Cellular Neuroscience 21 671-683. (doi:10.1006/mcne.2002.1189)

Vaudry D, Falluel-Morel A, Basille M, Pamantung TF, Fontaine M, Fournier A, Vaudry H \& Gonzalez BJ 2003 Pituitary adenylate cyclaseactivating polypeptide prevents C2-ceramide-induced apoptosis of cerebellar granule cells. Journal of Neuroscience Research 72 303-316. (doi:10.1002/jnr.10530)

Vaudry D, Falluel-Morel A, Bourgault S, Basille M, Burel D, Wurtz O, Fournier A, Chow BK, Hashimoto H, Galas L, et al. 2009 Pituitary adenylate cyclase-activating polypeptide and its receptors: 20 years after the discovery. Pharmacological Reviews 61 283-357. (doi:10.1124/ pr.109.001370)

Vertongen P, Delhase M, Rajas F, Trouillas J, Hooghe-Peters E, Svoboda M \& Robberecht P 1996 Pituitary adenylate cyclase-activating polypeptide/vasoactive intestinal polypeptide receptor subtypes are differently expressed in rat transplanted pituitary tumors (SMtTW) and in the normal gland. Journal of Molecular Endocrinology 16 239-248. (doi:10.1677/jme.0.0160239)

Wang X, Chu MM \& Wong AO 2007 Signaling mechanisms for $\alpha 2-$ adrenergic inhibition of PACAP-induced growth hormone secretion and gene expression grass carp pituitary cells. American Journal of Physiology: Endocrinology and Metabolism 292 E1750-E1762. (doi:10.1152/ajpendo.00001.2007)

Watanabe S, Itoh K \& Kaneko T 2016 Prolactin and cortisol mediate the maintenance of hypero-smoregulatory ionocytes in gills of Mozambique tilapia: exploring with an improved gill incubation system. General and Comparative Endocrinology 232 151-159. (doi:10.1016/j.ygcen.2016.04.024)

Wong AO, Leung MY, Shea WL, Tse LY, Chang JP \& Chow BK 1998 Hypophysiotropic action of pituitary adenylate cyclase-activating polypeptide (PACAP) in the goldfish: immunohistochemical demonstration of PACAP in the pituitary, PACAP stimulation of growth hormone release from pituitary cells, and molecular cloning of pituitary type I PACAP receptor. Endocrinology 139 3465-3479. (doi:10.1210/en.139.8.3465)

Wong AO, Li W, Lee EK, Leung MY, Tse LY, Chow BK, Lin HR \& Chang JP 2000 Pituitary adenylate cyclase-activating polypeptide as a novel hypophysiotropic factor in fish. Biochemistry and Cell Biology $\mathbf{7 8}$ 329-343. (doi:10.1139/o00-055)

Wong AO, Li W, Leung CY, Huo L \& Zhou H 2005 Pituitary adenylate cyclase-activating polypeptide (PACAP) as a growth hormone (GH)-releasing factor in grass carp. I. Functional coupling of cyclic adenosine $3^{\prime}, 5^{\prime}$-monophosphate and $\mathrm{Ca} 2+$ /calmodulin-dependent signaling pathways in PACAP-induced GH secretion and GH gene http://joe.endocrinology-journals.org

DOI: $10.1530 / \mathrm{JOE}-16-0433$
๑) 2017 Society for Endocrinology Printed in Great Britain 
expression in grass carp pituitary cells. Endocrinology 146 5407-5424. (doi:10.1210/en.2005-0294)

Xu M, Long L, Chen L, Qin J, Zhang L, Yu N \& Li E 2012 Cloning and differential expression pattern of pituitary adenylyl cyclaseactivating polypeptide and PACAP-specific receptor in darkbarbel catfish Pelteobagrus vachelli. Comparative Biochemistry and Physiology
Part B: Biochemistry and Molecular Biology 161 41-53. (doi:10.1016/j. cbpb.2011.09.005)

Zhou H, Ko WK, Ho WK, Stojilkovic SS \& Wong AO 2004 Novel aspects of growth hormone (GH) autoregulation: GH-induced GH gene expression in grass carp pituitary cells through autocrine/paracrine mechanisms. Endocrinology 145 4615-4628. (doi:10.1210/en.2004-0163)

Received in final form 6 January 2017

Accepted 27 January 2017

Accepted Preprint published online 27 January 2017 (c) 2017 Society for Endocrinology Printed in Great Britain
Published by Bioscientifica Ltd 